\title{
OPEN
}

Published online: 19 March 2020

\section{Publisher Correction: Interaction of the hydrogen molecule with the environment: stability of the system and the $\mathscr{P} \mathscr{T}$ symmetry breaking}

\author{
I. A. Wrona, M. W. Jarosik, R. Szczẹśniak, K. A. Szewczyk, M. K. Stala \& W. Leoński
}

Correction to: Scientific Reports https://doi.org/10.1038/s41598-019-56849-2, published online 14 January 2020

The original version of this Article contained an error in Affiliation 2, which was incorrectly given as 'Institute of Physics, Jan Długosz University, Ave. Armii Krajowej 19, 42-200, Częstochowa, Poland'. The correct affiliation is listed below:

Institute of Physics, Czȩstochowa University of Technology, Ave. Armii Krajowej 19, 42-200 Czȩstochowa, Poland.

This error has now been corrected in the HTML and PDF versions of the Article.

(c) (i) Open Access This article is licensed under a Creative Commons Attribution 4.0 International (c) License, which permits use, sharing, adaptation, distribution and reproduction in any medium or format, as long as you give appropriate credit to the original author(s) and the source, provide a link to the Creative Commons license, and indicate if changes were made. The images or other third party material in this article are included in the article's Creative Commons license, unless indicated otherwise in a credit line to the material. If material is not included in the article's Creative Commons license and your intended use is not permitted by statutory regulation or exceeds the permitted use, you will need to obtain permission directly from the copyright holder. To view a copy of this license, visit http://creativecommons.org/licenses/by/4.0/.

(C) The Author(s) 2020 